\title{
The Women Social Culture Within The Novel of Cinta Kala Perang Created By Masriandi Sambo
}

\author{
Rismawati, M.Pd ${ }^{1}$ \& Hendra Kasmi, M.Pd ${ }^{2}$ \\ \{rismawati@gmail.com ${ }^{1}$, Hendra.kasmi@gmail.com² \\ ${ }^{1,2}$ STKIP Bina Bangsa Getsempena, Indonesia
}

\begin{abstract}
This research which is related to the woman within the novel CINTA KALA PERANG is created by MasriandiSambo. The research scope of this research included culture values that affected of woman's attitude. Therefore, the problem formulation in this research is how the writer reveals the condition of women social culture within the novel CINTA KALA PERANG. The social culture which will be investigated has consisted of three aspects, such as the social culture of woman as an individual, family member, and society. The findings of this research are the sequences that contained woman social culture in the novel. The source information of this research was taken from the novel CINTA KALA PERANG written by MasriandiSambo. This study aimed to describe the condition of social culture affected of woman's attitude. This study used the qualitative method with the sociology of literature approach. The technique of data analysis used interpretation with hermeneutic literature.Based on the character in the novel Cinta Kala Perang, Masriadi Sambo describe a real social culture of women which develops in Acehnese society. For instance (1) Acehnese women is not going outside home at the night and do not go outside their home alone or without a friend, (2) Acehnese women is a tough women, able to do all the work that can be done by the man, (3) Acehnese women is a central of logistic in the home, (4) Acehnese women have important role in society, (5) Acehnese women do not marry anymore if their husband die first, (6) Acehnese women is a hard worker.
\end{abstract}

Keywords: Novel, woman, social culture

\section{Introduction}

This research related to women within the novel CINTA KALA PERANG. The research scope of this study included the condition of woman social culture. This study was conducted based on the following. The woman, both as the connoisseur of the creation, as an artist, and also as the character within, who was being the phenomenon issue after the feminist theory had been developed by the critical thinker and activist. Particularly in Aceh, the woman's problem is never faded away. Aceh is the area that has an enormous history about the most fabulous woman such as the first female captain in the world, KeumalaHayati, the heroine of CutNyakDhien, and Queen Safiatuddin.After Indonesia became independent, Aceh had 
become an integral part of the Unitary Republic of Indonesia (NKRI) that has continued to have problems with the center of the government. Aceh was suffered from prolonged conflict, natural disasters of earthquake and tsunami in December 2004. This situation was possible to have an impact on women's socio-cultural aspects of the conditions that underlie the attitude of women in Aceh. Lately, the issue of Acehnese women also affected the media proclamation which is detik.com that carried the high dowry value of women in Aceh. Moreover, the dilemma of the women problem was getting stuck, exploitation, abuse, torture, and even murder. This case was possible happened because of the socio-cultural shift in underlying attitudes of women. Thus, it became an important issue. The issue will be seen whether it is revealed and revealed in a literary work, especially in the literary novel of Aceh's 21 st century. Literary work was seen as a social phenomenon that is directly attached the community at the time, and all the problems were shown up with women's issue, such as the problems of love, difficulty, and bitterness of life. The issue of women in Acehnese literary works of the $21 \mathrm{st}$ century (2000-20016) was interesting to examine based on the crucial events mentioned above, namely prolonged conflicts, earthquakes, and tsunamis. The estimate of these events has shifted the cultural values that underlain women's attitudes. As a result, the problem formulated that what extent does MasriandiSambo reveal the socio-cultural conditions of women, in the novel Cinta Kala Perang?

Furthermore, the social culture will be described as follows. Social Culture consists of 2 words, the first social definition, according to the General Dictionary of Indonesian language by W.J.S Poerwadarminta (1966), social is everything that concerns society or can also mean to pay attention to the public interest. While the culture of the word Sans or Bodhya which means mind and reason. Culture is all things made by human beings based on thoughts and perceptions that contain creativity, taste, and intention. It can be art, knowledge, morals, law, beliefs, customs or knowledge. So the definition of social culture itself is all things created by man with his thoughts and conscience for and / or in the life of the community. In particular, this study aims to describe socio-cultural conditions that underlie the attitude of women. While the main benefits of this research are to make a significant contribution to the development of science in the field of sociology of literature, especially the study of women and the relation of the work of the novel with a real life. This study will illustrate and respond to the development, transition, or degradation of socio-cultural qualities of women, and will become a historical record for Acehnese women.

\section{Reseacrh Method}

This research is a research in the field of sociology of literature which involved women in literary texts. Women certainly have a significant role in a literary version and indeed, have nature and selfhood in society. Therefore, the most appropriate method used in this study is the qualitative method (Seger 2000: 68-70; Faruk 2012; Junus 1986: 3-4;)The findings in this research are sequences in the novel of Cinta Kala Perang by Masriandi Sambo. This novel is expected to contain the socio-cultural conditions of women. To obtain the data of the sociocultural conditions of women in Cinta Kala Perang novel by masriandi Sambo used reading and recording techniques patiently and accurately to avoid the data entry errors. As mentioned by Moleong (2003: 175-178) that to obtain accurate data required validity of checking data. There are ten techniques for examining the validity of data to serve as data in qualitative research, namely; (1) extension of participation, (2) observational persistence, (3) 
triangulation, (4) peer checking, (5) referential adequacy, (6) negative case studies , (7) member checks, (8) detailed descriptions, (9) dependency audits, and (10) audits of certainty.

\section{Result and Discussion}

\subsection{The General Overview Novel of Cinta Kala Perang}

This novel tells about a girl named Cut Tari. She was living at the foot of GunungLeuser after her father was shot by an unknown person when the war was still going on in Aceh. Tari only lives with her mother. "Emak," Tari call her mother in that way. Since the incident happened, Emak prohibited Tari to communicate with the military. Hearing the name of the army made Emak remembered that sympathetic story continuously.

Tari who began to fall in love with a soldier (Romi) deployed in the border provinces made Emak upset. Emak never liked the work related to violence. According to Emak, injuring others for any reason is not justified. Emakforbade her daughter to love the army. Even so, Emak tried to acceptthe reality and hope that her daughter's choice could make her child to be happy. Emak was passed away and left a message that Tari must be at peace with the situation. She could not revenge to against her father's killer. After her mother is gone, Tari lived with the ibu geuchik and appointed as her daughter. Tari decided to go to college. Working while studying in college was the right choice to cover living expenses.Tari was looking for a job everywhere made her unyielding. Finally, she became a private English teacher for a child of her lecturer (Pak Yoga). His name was little Ampon. Then, Tari was also accepted to work at non-governmental organizations advocating cases of violence experienced by civil society.

Tari met a military (Taufan) there. When she met Taufan at the first time, it recalled her about Romi who had gone somewhere without announcement. On several occasions met each other made Tari began to like Taufan. However, love could not grow when war is barking. Life could be lost every time. In war zones, love only grew the soul.

One day, Tari received a letter from a stranger. She opened and read the contents of the message. Apparently, the person who sent the letter was Romi's mother. For a long time, Romi's mother tried to find out of Tarii. After knowing where Tari was, his mother immediately gave information about Romi. Romi was shot on the battlefield, he was hospitalized, but God had another plan. Romi died. Hearing this news made Tari's heart was devastated. The man she had tried to forget was gone. Tari ever thought bad things about Romi. She thought Romi lied to her. At the same time, Taufan also leftthe battlefield and Return to Jakarta immediately. Even so, the love of the two servants of God stuck continuously. Time flew, since suffering from SLE disease, Tari should always do blood abstersion for the sake of healing. One day, Tari accepted the task of following the counseling in Jakarta. Tari was departed and having few days there. Before returning to Aceh, she intended to meet Taufan. She looked up the address which Taufan had sent by letter to Tari. Arriving at Taufan's house, she met with Taufan. Presumably, Taufan had a wife and a fiveyear-old child. Tari's heart was broken. Besides, she left Taufan's house and headed to the airport. With the permission of Taufan's wife, Taufan was chased Tari to the airport. On the way, Taufan got an accident. Tari had brought him to the hospital,yet Taufan Died. Tari returned to Taufan's house and saw crowded people and his child crying as well. Taufan's wife fainted and eventually died. Taufan and his wife died on the same day with a short span of time. Tari returned to Aceh. Ampon who had feeling for Tari expressed his feeling to her. He was helped by Indah. Tari did not want to receive Ampon at first because she suffered the illness. However, Ampon did not care about it. As a result, Tari accepts Ampon, and she 
informed to the $i b u$ geuchik in the village. The proposal process has taken place, and Tari was married to Ampon.

\subsection{Socio-Culture Underlying Women's Attitudes}

Social culture that underlined the attitude of women in this novel seen from some female characters. The social culture was closely related to norms and value systems that applied in a community of group, where women became members of society and desire to established relationships between people. The social culture of women referred in this study was the socio-cultural of women in the context of women as individuals, as members of the family, and as members of the community. The female characters mentioned in the novel of Cinta Kala Perang were Cut Tari, MakBenah, and Bu Nani.

\subsubsection{As Individual}

Individually, Tari understands the social culture which attached to herself. It is seen in the way she treats herself, for example not going out at night, and so without friends. But at an urgent moment, Tari is decided to go out at night looking for her Mother, even though she never went out at night. Tari's attitude showed the social culture that women was not right to went out the night even alone. This is evidenced by the following quotation, "I rounded a determination lead up to the village. Our hut is about three kilometers from the village. I never leave the house at night." Aside of Tari, in general people since the conflict never had activity at night. This is evidenced in the following quote, "Since the conflict occurred again two years ago, people are reluctant to open the door of the house at night."

Cut Tari was also a person who helped people indiscriminately. For her, if someone needs help, she will help as best as she can. She reflected as a good woman, this matter as in the following quote:

"I see a mother holding her baby. My heart moved to help my soul softly staring at the baby's funny eyes." (Sambo, 2014: 48)

Cut Tari was also a person who did not want to bother others in her duty also did not want to trouble others. It is like in the following quote:

"A small tent for the night has been prepared since the drizzle greeted, we did not want to trouble the villagers. Although the villagers offer to stay at their home, it's too much trouble for others." (Sambo, 2014: 89).

\subsubsection{As Member of Family}

The women have several roles in the family which are as a wife, as a mother for her children, and as a member of family. There are rights and obligations which attached to the women, just like Tari. The feeling of care and love toward a child which has been left by his/her mother (orphan) is massive in society (loving orphans). Tari stayed in Keuchik's home after her mother died. Keuchik is a leader in a village. Keuchik's family love Tari as much as they love their own child, as it revealed in the following quote "Keuchik and his wife considered me as their own child. They never ask me to do work at their rice field, but I feel that I owe gratitude to them my adoptive parents".

In Acehnese culture, the women are a central of domesticity activity which concentrate inside home only. The activity which can be done by the women is preparing food. As the following quotation tells:

"I prepare diner for mother. Our chicken and duck have also been put in the cage. (Sambo, 2014: 133)"

"I take a bath and prepare for dinner. (Sambo, 2014: 133)" 
It is depicted in the novel that Acehnese women is a very caring woman as described by $\mathrm{Bu}$ Nani character s who cares towards her husband. She also knows her obligation when her husband come home after all days looking for sustenance toward her and their baby later. It is like in the following quotation:

"We both went home. My husband leaned back on the wicker chair in the living room, while I went straight to the kitchen. A clink of glass clashing with a sob sounded into the living room, I immediately prepared my husband's favourite warm tea". (Sambo, 2014: 15)

$\mathrm{Bu}$ Nani feels having responsible nature for looking sustenance and become father for her children. She realized that her family rely on her because she lives as a single parent. She is able to provide for her family's need without relying on others. She does what the man should do. It is like in the following quotation:

"Immediately when morning arrives, the mother rushes to the forest, looking for wood as big as an adult arm and come back to home when azan magrib is echoing from meunasah (surau). (Sambo, 2014: 7)".

Dozens of firewood are neatly arranged on old wagons. it has become a living wagon for the family. (Sambo, 2014: 21)".

The women are depicted as a loyal character in Acehnese tradition, even after their husband die. The divorce and dead are considered as destiny which must be lived throughout live. The family will always give support to the widow which has been left by dead by her husband. They become a mother which has role as a remarkable father. The social culture of women in the family is very strong and fully responsible in leading the children to success.

\subsubsection{As Member of Society}

The women in Acehnese society have a very noble position. They are not distinguished toward man. The proof is when the mother is gone. The sense of mutual help is strongly stick to the society. They are all looking for mother even though it was night without light. They remain alert to help find the mother who was not home yet. The culture of not going home at the night makes Tari worried. The mother has not been at home since magrib. It is proved by the quotation "The Keuchik gathered a villager. Approximately, 20 people gathered in front of Keuchik's home. I was accompanied by Bu Keuchik. And we went to the city."

Although they do not know each other, the sense of mutual help was strongly stick to the society at that time. It can be seen from the following quotation "the villager and the people who carried mother's body brought mother's body to in front of Keuchik's home. Later I came to know that the man who carried mother's body was a bee seeker in the mountain."

Cut Tari's Relationship with individual looks friendly in the orientation stage at one of University. It is like in the following quotation:

"I smiled as I greeted the hand of the woman next to me. The Rector of university was giving a speech and delivering a message for the new students (Sambo, 2014: 71)".

As a social person, Cut Tari is always responsible for the work she is responsible forand does it with all her heart, as in the following quotation:

"I have to go to office at the morning, take care of conflict companions, invite them to talk if they feel sick. I take them to the hospital if there is trauma and I also bring in the psychiatry. A private teaching schedule, finishing collage assignment and of course attending the class. (Sambo, 2014: 124)"

$\mathrm{Bu}$ Nani has friendly nature as social person, helping each other because she knows that in life we should help the people who need or help. It is stated by her children, Cut Tari in the following quotation:

"the mother is recognized as cheap smile, good and compassionate all this time. Every time villagers ask for her help, she always does her best (Sambo, 2014: 33)" 
As a social person, MakBenah has a loving sense of mutual help among others who need her help because she realized that life is like spinning wheel, sometimes it is above and sometimes it is below. She considered that helping each other is alms. It is like in the following quotation:

"It is MakBenah who helped me to get a stall in the market, without having to pay a fix dues Rp. 5.000 each day (Sambo, 2014: 26-27).

The characters in Novel Cinta Kala Perang which was written by Masriadi Sambo are dominated by the women characters. The women character in the novel Cinta Kala Perangare Cut Tari, Bu Nani, MakBenah, Indah, MakMaimunah, Bu Keuchik, and Ratih. However, this paper is only nominated a few names of women characters from all the women characters in this novel. Only the main character and a figure which have important role in the story. Nevertheless, the presented analysis covers all the women character. The women character in Novel Cinta Kala Perang could be recognized through the reaction of character towards events within the story. The writer describes social culture of women through the technique of description by using expository technique and dramatic technique. The social culture of women looks very authentic which is revealed by women daily activity described in the novel Cinta Kala Perang.

The data analysis above shows that a very strong social culture of women which sticks to the daily life activity are as follow:

1. As an individual, the women in Aceh still preserve their dignity, family, and society, has a friendly nature and the sense of responsible. One of the way to show it is by not going outside their home in the night, and not going outside their home alone because it can cause defamation.

As a member of family, Acehnese women still hold the culture that women should able to cook, able tomanage their children, and obey to the husband even though their husband has already died, Acehnese women will always be loyal to their husband for the rest of their life. She will never marry anymore. The divorce and dead is sacred. Acehnese women is tough women. They are able to be relied on and can do what the man should do. Therefore, there is no gender differences in term of work.

In the novel Cinta Kala Perang, it is the women who worked hard and responsible for their own life. Furthermore, the women do not only stay at home to take care of their children and husband, but also the description of the women character in the novel is real-life description depicted by the writer. Nowadays, the condition of Acehnese women is the women workers which work in almost every field as it revealed by the character of Cut Tari and Indah in the Novel Cinta Kala Perang that work in Non-Governmental Organization known as LSM. From the first Acehnese women have been commonly working especially in urban women become teachers, lecturers, researchers and many other professions. This has been commonplace in Acehnese society as stated by (Bustamam, 2014). Bustamam stated that the women are in the corner of city with every profession. They are in that position because they are qualified to be in that position. By 1990, the profession on the roadside was dominated by man. Nowadays, that profession is slowly move to the women. It is the proofed that the women are equal to the man. Nowadays, Acehnese women is described as tough and great women. Therefore, it makes them to compete in healthy way.

The description above will result in social engineering for the resurgence of women in Aceh, apparently supported by infra-structures. In spite of negative and positive side that is happened, this is caused a lot of women have high education.

Socially, the female character in Novel Cinta Kala Perang, is friendly, courteous, kind, helpful to each other, and obedient to worship. Through the character of Cut Tari and some 
other female character in Novel Cinta Kala Perang, Masriadi Sambo shows how the real social culture of Acehnese women which has the role in society as the women which are independent, decisive, discipline, never give up and responsible for what she has done.

2. As a member of society, Acehnese women has a noble position. In maintaining social culture in society, the women have important role. In every society activity, there will be the women. It is related to the history which tells us that there are a lot of women who stood out in the past in term of leadership and resistance. Far away before the kingdom of Aceh Darussalam was built, the leadership of Kingdom in Aceh was hold by the women such as Malahayati, and Queen Syafiatuddin. The kingdom of Ache Darussalam gave a women significant role in military army. In the era of Sultan AlaudinRiayatSyah (15891604), The army of InongBalee was created which came from the widow of soldier who died in the war. This army was led by admiral Malahayati which was great in designing war strategy. In addition of InongBalee, there were also Si PaiInong (the palace guard regiment) which was created by Sultan Muda Ali RiayatSyah V (1604-1607) and was led by admiral LeurahGanti and young admiral Cut MeurahInseun. When Aceh entered a period of tension with Dutch colonialism, or better known as the Aceh war period, women also went ahead as the leader such as Cut NyakDhien, Cut Meutia, TeukuFakinah, PocutBaren and etc. Therefore, the image of Acehnese women is remarkably good in both as an individual and social.

\section{Conclusion}

The main character in novel Cinta Kala Perang is Cut Tari and other figures are Bu Nani, MakBenah, Bu Keuchik, Indah, Bu Maimunah, and ratih. They describe social culture of women as the whole even though they are different personality. Social culture of women is analysed through their role as an individu, as a member of the family, and as a member of society. Based on the character in the novel Cinta Kala Perang, Masriadi Sambo describe a real social culture of women which develops in Acehnese society. For instance (1) Acehnese women is not going outside home at the night and do not go outside their home alone or without a friend, (2) Acehnese women is a tough women, able to do all the work that can be done by the man, (3) Acehnese women is a central of logistic in the home, (4) Acehnese women have important role in society, (5) Acehnese women do not marry anymore if their husband die first, (6) Acehnese women is a hard worker

\section{References}

[1] Bustamam, Kamaruzzaman. 2014. Acehnologi. Banda Aceh: Bandar Publishing.

[2] Faruk. 2012. Metode Penelitian Sastra. Jakarta:Pustaka Pelajar

[3] Junus, U. 1986. Sosiologi Sastra: Persoalan Teori dan Metode. Kuala Lumpur: Dewan Bahasa dan Pustaka

[4] Moleong, Lexy.J. 2003. Metodologi Penelitian Kualitatif. Bandung: Remaja Rosdakarya.

[5] Poerwadarminta, WJS. 1966. Kamus Umum Bahasa Indonesia. Jakarta: Balai Pustaka

[6] Sambo, Masriadi. 2014. Cinta Kala Perang. Jakarta: Alex Media Komputindo.

[7] Segers. 2000. Evaluasi Teks Sastra (terjemah Suminto. A. Sayuti. Yogyakarta: Adicita 